\title{
AMERİKALI TÜRKLER
}

\author{
Turkish Americans
}

\author{
İhan Kaya \\ Dicle Üniversitesi, Ziya Gökalp Eğitim Fakültesi, \\ Sosyal Alanlar Eğitimi Bölümü, Coğrafya Eğitimi Anabilim Dalı 21280, Kampüs, Diyarbakır \\ ilhankaya@dicle..edu.tr
}

\begin{abstract}
Özet: Bu makalede, Osmanlı Imparatorluğunun son zamanları ve Türkiye Cumhuriyeti tarihi boyunca Türklerin Amerika Birleşik Devletleri'ne olan göç eğilimleri incelenmektedir. Bunu yaparken de göç eden insanların sosyo-ekonomik arka-planları ve bu arka-planların ABD'deki yaşama uyum sağlama üzerindeki etkilerini irdelenmektetir. Ayrıca ABD'nin göçmen politikaları ve yasalarının, Türklerin göç hareketleri üzerindeki etkileri, diğer göçmen grupları ile paralelliklere/farklllıklara dikkat çekilerek açıklanmaktadır. Son olarak ta Türklerin ABD'deki dağılımı ve çok kültürlü/çok uluslu Amerikan toplumundaki sosyo-ekonomik durumu tartışlmaktadır.
\end{abstract}

Anahtar kelimeler: Amerikalı Türkler, Göç, Uyum, Türkiye, ABD

\begin{abstract}
This article examines Turkish immigration waves to the United States, which began in the last years of the Ottoman Empire and continued throughout the republican era. This is done by exploring the backgrounds of the immigrants and by investigating the role of these backgrounds in the integration process. It also looks at the role of American immigration laws in Turkish immigration waves by comparing and contrasting Turkish immigration with immigration of other groups. Finally, the article lays out the distribution of Turkish Americans in the United States and investigates their socioeconomic status in the multicultural and multiethnic American society.
\end{abstract}

Key words: Turkish Americans, Immigration, Integration, Turkey, USA

\section{Giriş}

Küreselleşme, nedense genelde dünyadaki değişik kültür, millet ve etnik grupların aynılaşması olarak algılanmakta; bu da genellikle dünyanın batılılaşması ya da Amerikalılaşması gibi tek yanlı bir homojenleş(tir)me olgusu olarak anlaşılmaktadır. Halbuki küreselleşme çok yönlü bir etkileşimi temsil eder. Kapitalist pazar ekonomisi, dünyadaki bütün milletleri ve kültür gruplarını birbirlerine bağımlı hale getirmiş, iletişim ve ulaşımdaki baş döndürücü ilerlemeler, uluslar ve kültürler arasında etkileşimi kolaylaştırarak coğrafi mesafenin uzaklığını sembolik bir dereceye indirmiştir (Giddens, 2000; Gregory, 1995). Teknolojideki bu hızlı gelişimin getirdiği kolay seyahat ve iletişim, değişik etnik, dini ve kültürel grupların etkileşimini kolaylaştırmakla kalmayıp, birbirine yabancı grupları yüz yüze getirmekte ve farklılıklarına rağmen beraber yaşamasını zorunlu kılmaktatır (Appadurai, 2000).

Dolayısıyla, küreselleşme olgusu düşünülürken Amerikan ya da batı kültürünün aynılaştıran (homojenleştiren) özelliğinin yanında, farklı kültürel ve etnik grupların "homojen" kültürleri farklılaştırmasının da sözkonusu olduğunu unutmamak gerekir (Appadurai, 2000). Nisbeten "homojen" ulus-devletler içindeki göçmen gruplarının varlığı ve bu ulus-devletlerin siyasi, ekonomik ve kültürel yapısı üzerindeki heterojenleştirme etkileri ise küreselleşmenin en önemli yanlarından birisidir (Barber, 1996). Sözkonusu farklılaştırma faaliyetinin arkasındaki en etkin dinamiklerden biri 
ise "göç”ttür (Appadurai, 1998). Bu makale, Türklerin Amerika Birleşik Devletleri (ABD) göçünü küreselleşme perspektifi açısından irdelemektedir.

Her göç eden kültürel grup, vardığı ülkeye kendi gelenek, görenek ve değerleri ile birlikte, yaşam tarzını taşır. Göçmen gruplar, baskın kültür içinde farklı kültürel kimlik ve değerleri temsil eden sosyo-kültürel adacıklar oluşturarak kurdukları dernek, okul ve ibadet yerleri vasitasıyla kimliklerini korumaya, kendi gelenek ve inançlarını yaşatmaya çalışırlar (Benmayor \& Skotnes, 1994). Bunu yaparken de parçası oldukları yeni toplumu belli ölçülerde yeniden şekillendirme sürecine katkıda bulunurlar. Fakat her yeni göçmen, parçası olduğu bu yeni toplumu şekillendirirken kendisi de değişir, dönüşür ve yeniden şekillenir (Jackson, 1994). Buradaki en önemli olgu ise farklı ideolojiler, kültürel ve siyasal etkilerin etkisi altındaki bireylerin yaşadığı kimlik mücadelesidir (Palanithurai \& Thandavan, 1998). Bu olgu, farklı etkiler altındaki bireyin kimliğinin ve değerlerinin, sürekli bir mücadele alanına (battle ground) dönüşmesi şeklinde anlaşlabilir. Bir yandan "eski" değerlere sadakat, diğer yandan yeni ortamın sunduğu imkanlar ve değerler arasında tercihte bulunma, her göçmenin yaşadığ 1 bir mücadeledir (Cornell \& Hartmann, 1998).

$\mathrm{Bu}$ çalışma Amerikalı Türklerin karşı karşıya kaldığı kimlik mücadelesini ve ABD’ye entegre olma sürecini, göç tarihi ile analiz etmektedir. ABD'nin duyduğu iş gücü ihtiyacından ötürü Atlantik Okyanusu'nu aşarak ABD'ye giden Türkler, önceden sorgulamadıkları, hakkında düşünmedikleri kimliklerini bir şekilde anlama ve tanımlama durumunda kalmaktadırlar. Yıılarca benzerleri (diğer Türkler veya Türkiyeliler) ile aynı ortamda (Türkiye) olan Türk göçmenler, yeni mekanlarında farklı anlayış ve yaşam tarzları ile karşılaşınca, kendi farklılıklarına karşı daha duyarlı hale gelmekte ve kendilerini tanımlama zorunda kalmaktadırlar (Appadurai, 1998). Bu halleriyle de Anthony Giddens'in (1991) bahsettiği "küreselleşmenin farkl1lıkları yoğunlaştırması" olayına güzel bir örnek teşkil ediyorlar.

$\mathrm{Bu}$ makalede, Osmanlı İmparatorluğunun son zamanları ve Türkiye Cumhuriyeti tarihi boyunca Türklerin Amerika Birleşik Devletleri'ne olan göç trendlerini incelenmektedir. Bunu yaparken de göç eden insanların sosyo-ekonomik arka-planları ve bu arka-planların ABD'deki yaşama adapte olma üzerindeki etkilerini irdelenmektedir. Ayrıca ABD'nin göçmen politikaları ve yasalarının, Türklerin göç hareketleri üzerindeki etkileri, diğer göçmen grupları ile paralelliklere/farklılıklara dikkat çekilerek açıklanmaktadır. Son olarakta Türklerin ABD'deki dağılımı ve çok kültürlü/çok uluslu Amerikan toplumundaki sosyo-ekonomik durumu tartışılmaktadır.

Çalışmanın önemli bir ikilemi, standart bir Türklük tanımının sunulamaması ve Türk göçmenlerinin kesin bir rakamının tespit edilememesidir. $\mathrm{Bu}$ çalışmaya veri kaynağ göçmenlik bürosu, Osmanlı İmparatorluğu'dan ABD'ye gelen bütün göçmenleri, etnik ve dini farklılıklarına bakmaksizin Türk olarak kayıtlara geçirmiştir. ABD'ye gelen Osmanlı göçmenleri sadece Türkleri değil, aynı zamanda Ermeni, Rum, Yahudi ve Arab Hıristiyanlar gibi gayrımüslim Osmanlı vatandaşlarını da kapsıyordu (Karpat, 1995). Bunun yanısıra Müslüman Araplar ve Kürtler de ABD kayıtlarına Türk olarak geçirilmiştir. Bugün de aynı sorun sözkonusu; çünkü göçmenlik bürosu, Türkiye Cumhurüyeti'nden ABD’ye göç eden bütün Türk vatandaşlarını Türk olarak kayıtlara geçirmektedir. Bu durumda, Osmanlı İmaparatorluğu ve Türkiye Cumhuriyeti'nden ABD’ye göç edenlerin ne kadarının etnik Türklerden ne kadarının Türk olmayan azınlıklardan müteşekkil olduğunu tespit etmek oldukça güçtür. Dolayısıyla verilen rakamlar tahminlere dayalıdır.

$\mathrm{Bu}$ araştırma, Osmanlı İmparatorluğu'dan ABD'ye göç eden Türkleri etnisite tanımlaması içinde ele almaktadır. Haliyle, Osmanlı Türklerinden bahsederken Osmanlı vatandaşlarının etnik olarak Türk olanları kastedilmektedir. Bu tanımlamaya Osmanlının Ermeni, Rum ve Musevi gibi gayrımüslim vatandaşları ile Müslüman Araplar dahil değildir. Ancak, İkinci Dinya Savaşı sonrası göçlerle Türkiye'den ABD'ye giden göçmenler için kullanılan tanımlama ise Türk vatandaşlı̆̆ıdır. Dolayısıyla, Türkiye'den ABD'ye giden herkes bu çalışmada Türk olarak değerlendirilmektedir. 


\section{Göç Tarihi ve Başlıca Nitelikleri}

Türklerin ABD’ye göçleri 1820’li yıllara dayansa da, kayda değer göç hareketleri 19. yüzyılın son çeyreğinde başlar ve 20. yüzyılın hemen başında doruk noktasına ulaşır. Amerikan göçmen bürosu verilerine göre 1820-2000 tarihleri arasında Osmanlı imparatorluğu ve Türkiye Cumhuriyeti'nden 450,539 kişi ABD'ye göç etmiştir (INS, 2001). Özelikle, Osmanlı Imparatorluğunun son yılları, ABD’ye göçün doruğa ulaştı̆g zamanlardır. Örneğin, 1900-1920 tarihleri arasında 291,435 göçmen Atlantik Okyanusunu aşarak ABD'ye gitmiştir (Sekil 1). Göçün en yavaş olduğu dönem ise iki cihan harbi arasındaki tarihlere tekabül eder. Özellikle de 1930'lu yıllar, Türkiye'den ABD'ye göçün en düşük olduğu yıllardır (INS, 2001).

Tarihsel boyutta Türklerin ABD’ye göçü incelendiğinde, üç farklı "göç dalgasının" varlığı dikkati çeler. Birinci dalga, düşük gelirli ve eğitim düzeyi düşük Osmanlı köylüsünü temsil etmektedir. 20. yüzyılın başında Osmanlı İmparatorluğu'nun yaşadığı ekonomik çöküntü, ABD’ye yapılan ilk göç dalgasının en önemli itici faktörüdür. İkinci göç dalgası, 1950 ve 1960'lı yıllarda ABD'ye akın eden eğitim düzeyi yüksek "Cumhuriyet çocuklarını" temsil etmektedir. Son dalga ise, 1980'li yılların sonlarında ABD'ye gelen, farklı sosyal ve ekonomik grupları kapsayan kozmopolit bir grubu karakterize eder.

\subsection{Birinci Dalga: Osmanlı Türkleri}

Birinci göç dalgası 1820 'de başlayıp, birinci dünya savaşının sona ermesi ile biten yaklaşık yüz y1llık bir dönemi ihtiva eder. Amerikan göçmen bürosu verilerine göre, bu dönem zarfinda 300 bine yakın kişi Osmanlı İmparatorluğu'ndan ABD'ye göç etmiştir (Şekil 1). Osmanlı Devleti kaynakları ise 1885-1912 arasında 80,000 kişinin ABD’ye göç ettiğini göstermektedir (Karpat, 1995). Frank Ahmed'e (1986) göre aradaki fark Osmanlı devletinden göç eden bir çok göçmenin, devletten izinsiz olarak ABD'ye göç etmesinden kaynaklanmaktadır. Anadolu köy ve kasabalarından gelen bu birinci dalga göçmenler, Trabzon ve Samsun limanlarından findık yükleyen Fransız gemilerine binerek Marsilya üzerinden ABD'ye geçiyorlardı (Ahmed, 1986). Amerikan göçmen bürosu Osmanlı Devleti ve Türkiye'den 1920 yılına kadar göç eden insanlar için, yaklaşık 300 bin gibi bir rakam vermesine rağmen ilk göçmenlerin bir çoğu aslında etnik Türkler değildi. Etnik sınıflandırma probleminden dolayı göçmen bürosunun bu döneme ilişkin kayıtları, yukarıda zikredilen sebeplerden dolayı gerçeği yansıtmaz. Buna rağmen Altschiller (1995) ve Frank Ahmed (1986) 1920'li yıllara kadar ABD'ye gelen Müslüman Türklerin sayısını 45 bin ile 65 bin arası gibi bir rakam olarak vermektedirler.

İlk göç dalgasında dikkat çeken diğer önemli noktalardan birisi de, göçmenlerin Türkiye'deki ikamet yerleridir. Türk göçmenlerinin bir çoğu Harput (Elazığ), Antep, Trabzon, Akçadağ, Dersim (Tunceli), Siverek, Rize ve Samsun gibi daha çok Anadolunun doğusundan diyebileceğimiz kentlerden geliyorlardı (Ahmed, 1986). Izmir ve Mersin'den de göç edenler olmuşsa da, büyük çoğunluk yukarıda bahsedilen bölgelerdendi. Göçün çoğunlukla, söskonusu yerlerden olması da sebepsiz değildi. Harput'taki Amerikan misyoner okulu, sadece o bölgedeki Hıristiyan Ermenilere yardımcı olmuyor, aynı zamanda ABD'de ki zenginlikleri ve imkanlarından bahsederek, bir çok Anadolu insanının da bilgilenmesini sağlıyordu (Karpat, 1995).

Birinci göç dalgasıyla ABD’ye gelen Türklerin diğer bir özelliği ise, kendilerini Türk olarak değil de, Osmanlı ya da Müslüman olarak tanımlıyor olmalarıydı. Türkiye'den ayrıldıkları zaman Türkiye Cumhuriyeti henüz kurulmadığı ve ulusçu düşünceler yaygınlaşmadığından, ulusçuluk fikri onlar için çok fazla bir anlam taşımıyordu. Kimliğin asıl belirleyicisi ulustan ziyade din idi (Ahmed, 1986). 


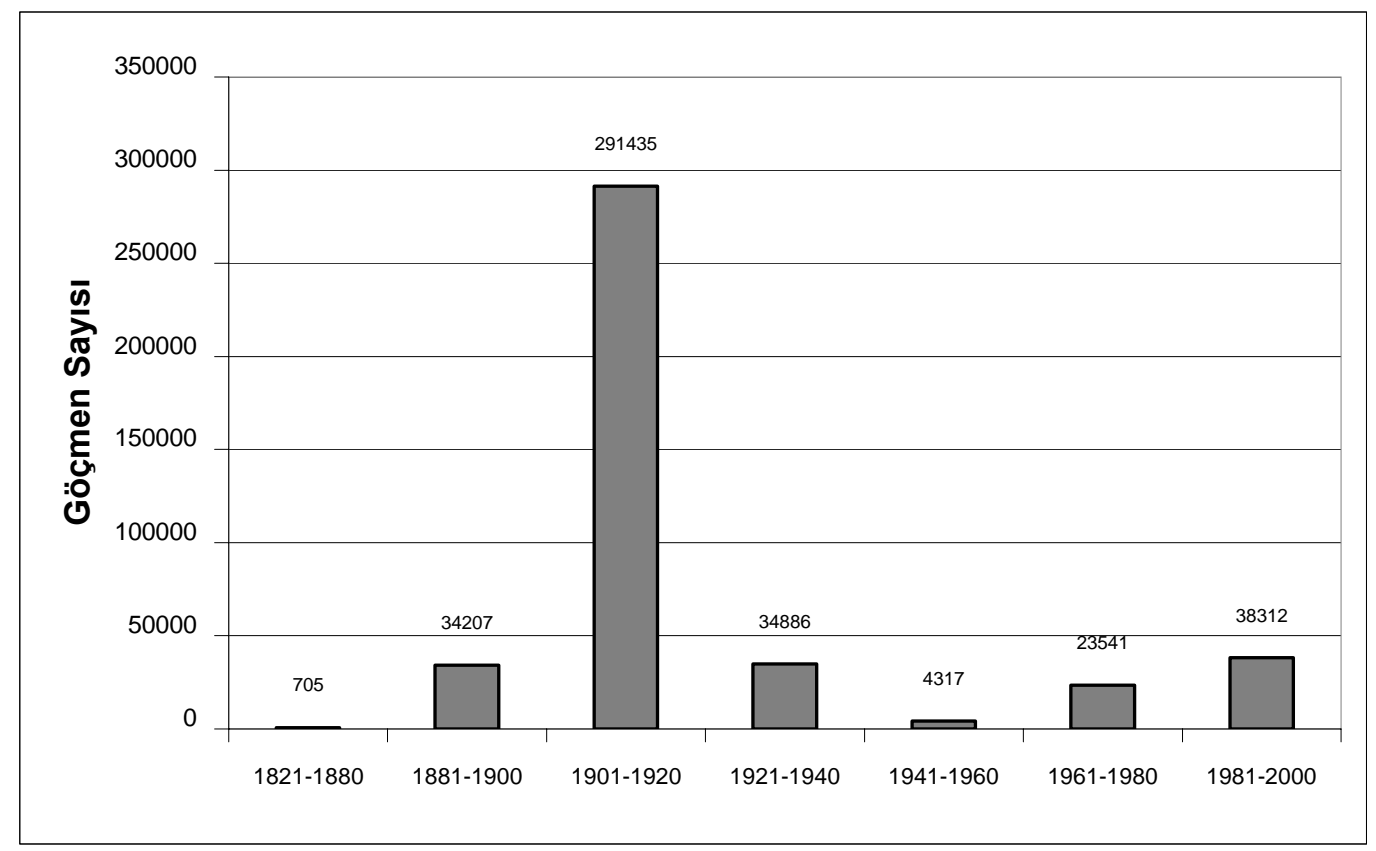

Şekil 1. Türklerin ABD’ye göçleri (1820-2000).

Kaynak: United States Immigration and Naturalization Service, 2000.

Birinci göç dalgasındaki Türklerin göçlerinin temel sebebi ekonomikti. Bir yandan Osmanlı Devleti'ndeki ekonomik zorluklar, öte yandan ABD'nin duyduğu iş gücü ve sunduğu iş imkanları, ABD'ye göçü cazip hale getiriyordu. Göç eden Türklerin hemen hepsi genç ve bekar erkeklerden oluşuyordu. Türkler, eşleri ve çocuklarını ABD gibi uzak ve Müslüman olmayan bir diyara götürmek ya da arkalarında kendilerini yıllarca bekleyecek birilerini bırakmak istemiyorlardı. Bu y1llarda ABD'ye göç eden Türklerin anlattı̆̆ 1 hikayeler zamanın şartlarından ve insanların olaya bakışı açısından ilginç kesitler sunmaktadır. Frank Ahmed'in (1986, s. 86) kitabında aktardığı genç bir adamın hikayesi şöyledir;

20 yaşında ve arkadaşlarımın gözünde güçlü ve kuvvetli biriydim. Çalışmak istiyordum fakat iş yoktu. Çaresizdik. Bugünün Türkiyesinde bunu anlamak güç olabilir. Bu gün bir çoğumuz 1912 standartlarına göre zenginiz. İşimizin ve aşımızın olmadığı bu çaresizlik zamanında duyduk ki Amerika gibi bir ülke varmış. Orada iş çok ve işçiye ihtiyaç varmış. Çünkü bu ülkenin nüfusu çok azmış. Sakat veya kör olmayan herkes için iş olduğunu duyduk. Amerika'nın hiç kimsenin milliyetine bakmadan herkese kucak açtığını duyduk ve hissettik. Köye bu haberi ilk kez kimin getirdiğini bilmiyorum, fakat bütün konuştuğumuzun bu konu olduğunu çok iyi hatırlıyorum. Amerika yaşam ümidimiz olmuş, rüyalarımıza girmişti.

Binlerce genç ve bekar Türk erkeği, memleketlerini bırakıp, yeni fırsatlar ülkesi diye işittiği ABD'ye göç ettiler. Bu gençlerin, kol gücü dışında bir becerileri olmadığı gibi, gittikleri toplumla iletişim kuracak bir dilleri de yoktu. Çoğu henüz bir Anadolu kenti bile görmemiş, kırsal kesimden gelen bu delikanlıların tek varlıkları, kendilerini her şeye rağmen bilinmeyenler diyarına götüren cesaretleri idi. Gittikleri diyar sadece uzak değil, aynı zamanda çok farklıydı.

Türklerin göç ettiği yerler, ABD endüstrisinin işçiye ihtiyaç duyduğu New York, Massachussetts, Michigan, Illinois, Pennsylvania gibi endüstrinin ağırlıkta olduğu eyaletlerdi. Chicago, Pittsburgh, Detroit, Philedelphia, New York, Peabody, Salem gibi şehirler Türklerin akın ettiği endüstri merkezleriydi (Halman, 1980). Avrupa'nın değişik ülkelerinden gelen diğer göçmenler gibi Türkler de Ellis adasından ABD'ye geçiş yaptıktan sonra diğer bölgelere dağıllyorlardı. Ellis adası Amerikalı yetkililerin, bütün göçmenlerin sağlık kontrolunu yaptığı ve sorguya çektiği bir 
mahşer yeri gibiydi. Bir çok Müslüman Türk, Müslüman oldukları için ülkeye sokulmayacağı endişesini taşıyordu. Bu endişelerden dolayı, giriş kapısında müslüman olduklarını deşifre edebilecek isimlerini değiştirenler de az değildi (Ahmed, 1986). Bekir Baker, Hüseyin Sam, Ali Alli, Ahmet Frank oluyordu. Ülkeye kabullerini kolaylaştırmak için izledikleri diğer bir strateji ise, kendilerini Ermeni ya da Süryani olarak takdim etmeleriydi. Böylece geçişlerinin daha kolay olacağını düşünüyorlardı. Balkanlardan gelen Türkler de vardı. Onlar da sınır kapısındaki Amerikalı görevlilere kendilerini Arnavut, Bulgar ya da Sırp olarak tanıtıp ABD'ye kabullerini kolaylaştırmaya çalışıyorlardı (Ahmed, 1986).

ABD'ye birinci göç dalgası ile gelen Türklerin ABD'deki hayatları, yaşadıkları zorluklar ve yeni topluma entegrasyonları hakkında bilgilerimiz oldukça sınırlıdır. Frank Ahmed'in yazdığı “ABD'deki Türkler: Osmanlı Türk'ünün Göçü” bu anlamda en önemli kaynaktır. Ahmed'e (1986) göre, Anadolu köylüsünden oluşan birinci göç dalgasındaki Türklerin, ABD’ye gelişlerindeki temel sebep ekonomikti ve hiç bir göçmen ABD'ye yerleşmek maksadıyla gelmiyordu. Asıl gaye bir kaç sene çalışıp, para biriktirip, geldikleri köylerine zengin olarak dönmekti. Bu paralarla daha sonra ev, arsa alacak ve rahat bir hayat sürdüreceklerdi.

Ilk Türk göçmenleri, çoğunlukla New York, Detroit, Chicago ve Boston gibi şehirlerdeki fabrikalarda, gelir gelmez iş bulabiliyorlardı. Aralarında bir kaç kişinin, Ingilizceyi biraz anlaması ve konuşması, diğerlerinin iş ve kalacak yer bulması için yeterliydi. Ahmed (1986) ve Karpat'a (1995) göre kültürel ve dini farklılıkların yanında Ingilizce bilgisindeki eksiklikler, bir çok Türk'ün Amerikan toplumundan kopuk bir hayat sürmesine sebep oluyordu. Kısa zamanda Türklerin ve Rumların açtıkları kahvehaneler, memleket hasreti ile yanan Türkler için önemli bir buluşma yeri oldu. Buralarda kağıt oynayıp sohbet ederek hem eski alışkanlıklarını devam ettiriyor, hem de memleket hasretlerini unutmaya çalışıyorlardı.

$\mathrm{Bu}$ şekildeki, içinde yaşadığı toplumdan izole hayat tarzı, İkinci Dünya Savaşı'ndan sonra değişmeye başlamıştır. Türkiye Cumhuriyetinin 1923'de ilan edilmesi ile birlikte ABD'deki Türklerin neredeyse yarısı anavatana dönmüş̧ür (Ferris, 1995). Kalanlar ise artık ABD'de kalıcı olmaya karar verip, İrlandalı, İtalyan ve Fransız bayanlarla evlenip yeni memleketlerinde yuva kurarak yeni bir hayata başladılar. Bir kısmı gelenek ve kültürel değerlerini korumaya çalışsa da, bu yeni durum asimile olma yönünde bir başlangıç teşkil ediyordu. Nitekim bütün çabalarına rağmen, küçük bir azınlık halindeki Türk göçmenler, ilerleyen yıllarda Amerikan toplumu içerisinde kaybolup gideceklerdi.

Amerika Birleşik Devletleri 1924 yılında göçmenlik yasalarında büyük değişiklikler yapmış, bir kısım ülkelerden göçü ciddi şekilde sınırlamıştı. 1924 göçmenlik yasası, ABD'ye göçlerde ABD'de yaşayan değişik grupların ulusal kökenlerini esas alıyordu. Yani bir ülkenin ABD'ye göç vermesi büyük oranda ABD'ye daha önce gelmiş göçmenlerinin sayısına bağlıydı (Shanks, 2002). Bu durumda İngiltere gibi ülkeler, uygulanan göç kotasından pek fazla etkilenmiyor, aksine ABD’ye göç verme yönüyle avantajlı duruma geliyorlardı; çünkü ABD'de İngiltere kökenli vatandaşların sayısı oldukça fazla idi.

Amerika Birleşik Devletleri 1924 yılında göçmenlik yasalarında büyük değişiklikler yapmış, bir kısım ülkelerden göçü ciddi şekilde sınırlamıştı. 1924 göçmenlik yasası Türkiye’ye ise yıllık yüz kişilik bir kontenjan öngörüyordu. Ancak Türklerin ABD’ye göç etmekteki isteksizliği nedeniyle, 1930-1940 yılları arasında Türk göçü yüz kişilik kontenjanı bile doldurmuyordu. Bu kontenjanlardan öncelikle faydalananlar ise ABD'deki akrabası olan Türk göçmenlerdi (Shanks, 2002). Birinci Dünya Savaşı sonrası Türk göçünün azalmasının önemli bir sebebi, yeni kurulan Türk devletiydi. 1923'te kurulan Türkiye Cumhuriyeti, Türk milleti için yeni ümitleri beraberinde getirmiş ve başka yerlerde fırsatlar aramasına gerek bırakmamıştı (Halman, 1980). Hatta Cumhuriyetin kurucuları, Doğu Avrupa ve $A B D$ gibi dünyanın değişik taraflarında yaşayan Türkleri Türkiye'ye dönmeye teşvik ediyordu. Ortaya çıkan bu yeni durum, Türklerin ABD'ye ilgisini azaltarak, Türk göçünün büyük ölçüde düşmesine sebeb olmuştur. 
ABD’ye göçün azalmasının diğer bir sebebi de, Türkiye'den göç etmek isteyen gayrımüslim Osmanlı/Türk vatandaşlarının sayısında meydana gelen azalmadır. Zaten yıllarca Türkiye dışına yaşanan gayrımüslim göçü giderek azalmış, geriye kalanların hakları ise 1923 Lozan Antlaşması ile güvence altına alınmıştı (Lewis, 1961). Onlar da yeni şartlar altında göç etme ihtiyacı duymamışlardır (Bali, 2004).

Neticede, Birinci Dünya Savaşından sonra Türkiye'den ABD’ye göç, ciddi bir şekilde yavaşlayarak yı1lık yüz kişinin altına düşmüsşür. Haliyle, 1930-1950 yılları arası Türkiye'den ABD'ye göçün en yavaş olduğu dönemleri temsil etmektedir (Altschiller, 1995). Ancak İkinci Dünya Savaşından sonra, Türkiye'ye tanınan yıllık yüz kişilik kontenjan yetersiz olmaya başlamıştır. Bu durum ABD’nin 1965 yılında yaptığı yeni göçmenlik yasasıyla ciddi anlamda değişmiş ve Türk göçünün yeniden artmasını sağlamıştır.

\subsection{Geriye Dönüş}

Türklerin ABD’ye göçlerinin dikkat çeken ilginç bir yanı ise, Birinci Dünya Savaşı öncesi ABD'ye giden Türklerin, savaşın bitimi ve Türkiye Cumhuriyetinin kurulması ile birlikte, geriye dönmesidir. Karpat'a (1995) göre ABD'deki Türklerin Türkiye'ye dönüş oranları, geriye dönen Hıristiyanların üç katından daha fazla idi. Ahmed (1986) ABD'den Türkiye'ye geri dönen Türklerin rakamlarını 25,000 olarak verirken, Halman (1980) geriye dönüşlerin yüzde seksenlere vardığını ifade etmektedir. Geriye dönüşler ABD'de kalan Türkler üzerinde de büyük etkiler bırakmıştır. Önceleri bir çok Türk'ün yaşadığı mahalleler bu dönüşler nedeniyle boşalmaya başlamıştır. Türkler, çoğunlukta oldukları semtlerde azınlık durumuna düşmüş ve bu durum, kalanlar üzerinde duygusal olarak olumsuz etkiler bırakmıştır.

Bugün bir çok Türk'ün yaşadığı geriye dönüp dönmeme yönündeki kararsızlık, ilk Türkler için de sözkonusuydu. 2002 yılı ABD Kongresi milletvekilleri seçimlerinde Demokrat Parti'nin aday adaylarından Osman Bengur (Oz Bengur)'ün makalenin yazarına aktardığına göre, babası, ABD'de geçirdiği kırk yıla rağmen, Türkiye'ye geri dönmeyi düşünmüş, fakat bir türlü dönememişti. ABD'ye geçici olarak gelmiş olmanın verdiği duyguyla bir çok Amerikalı Türk, bir gün mutlaka döneceğini düşünmüş ancak bir çoğu neticede dönmemiştir. ABD'de geçici yaşama düşüncesinin, ABD'deki Türk toplumu üzerinde olumsuz etkiler bıraktığını da unutmamak gerekir. Kalıcılığın önemli belirtilerinden olan kurumsallaşma, ilk Türkler arasında oldukça düşük düzeydeydir. Okul açma ve dernek kurma gibi müesseseleşme faaliyetleri, daha çok İkinci Dünya Savaşından sonra giden Türkler tarafından gerçekleştirilmiştir.

\subsection{Ikinci Dalga: Profesyoneller}

Birinci Dünya Savaşını takip eden 30 küsür süre içerisinde Türkiye'den ABD'ye göç, en düşük düzeyde gerçekleşti. 1930 ve 1940'lı yıllarda yıllık Türk göçmen sayısı yüz bile değilken, 1950'lerin sonlarından itibaren ciddi artışlar oldu. Özelikle 1965 yılında ABD hükumetinin düzenlediği yeni göçmen yasası ile göç dalgası oldukça yüksek bir seviyeye ulaştı (Şekil 2). Johnson hükumetinin yaptığı 1965 tarihli göçmenlik yasası, göçlere liberal bir yaklaşım getirerek, ABD’ye göçü ulusal orijin, ırk ve din kriterlerine göre ayarlayan ayrımcı nitelikteki 1924 yasasını yürürlükten kaldırdı (Shanks, 2002). 1924 göçmenlik yasası Rusya, Polonya ve Italya gibi Avrupa ülkeleri ile birlikte, bir çok uzak doğu ülkesi ve Türkiye gibi Müslüman ülkelere de kotalar öngörüyordu. Bunun sonucu olarak ta, bu ülkelerden ABD'ye göç minimum seviyeye inmişti. 1965 yasası ABD'ye göç verebilecek ülke ve millet çeşitliliğinin artması için gerekli olan düzenlemeleri sağlamış ve Türkiye gibi ülkelerden ABD’ye göçün ciddi oranlarda artmasını sağlamıştır.

1950-1980 arasındaki otuz yıllık süre zarfında 27 binin üzerinde Türk ABD’ye gitmiştir. Bu rakamın 23 binden fazlası 1960 sonrasına tekabül eder (INS, 2001). 1970'li yıllara gelindiğinde, Türk göçmen sayısı giderek artmış ve yıllık iki binin üzerinde gerçekleşmişti. Dolayısıyla 1965 göçmenlik yasası, Türklerin ABD’ye göçleri açısından oldukça önemli bir dönüm noktası teşkil etmektedir. 


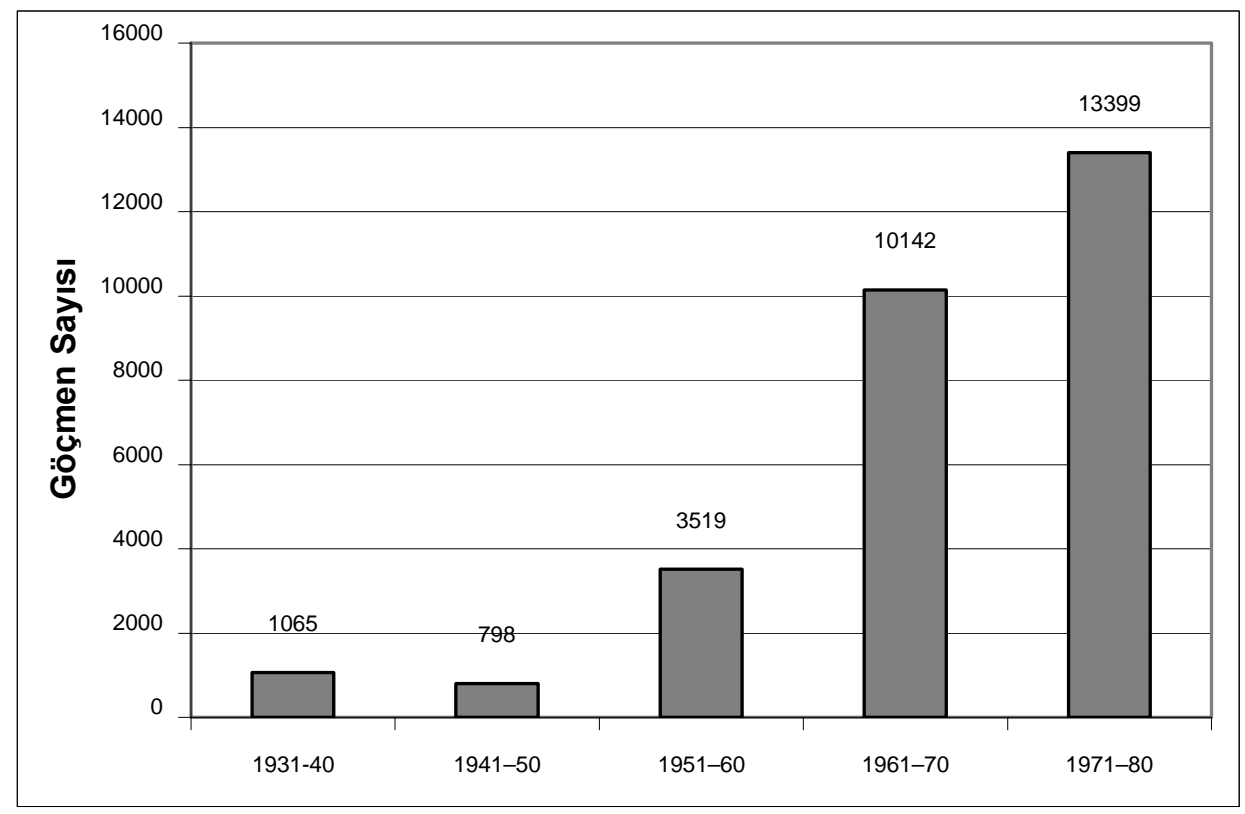

Şekil 2. Türklerin ABD’ye göçleri (1930-1980).

Kaynak: United States Immigration and Naturalization Service, 2000.

Bir önceki göç dalgasındaki Türklerle kıyaslandığında, çok büyük farklılıklar arz eden ikinci göç dalgasını oluşturan Türkler (1950-1980 arası göçmenler), Türkiye dışına yaşanan beyin göçünün de öncüleri olmuşlardır. Oldukça ulusçu ve seküler olan bu gruptaki Türkler, doktor, mühendis, mimar ve akademisyenlerden oluşan yüksek eğitimli profesyonellerdi (Karpat, 1995). Kendilerini dini kavramlar yerine ulusçu kavramlar ile tanımlıyorlar, Türklüklerini ön plana çıkarıyorlardı. Ağırlıkta erkeklerden oluşan bu profesyoneller arasında, önceki göç dalgasına nisbeten daha fazla kadın göçmen vardı. Çeşitli profesyonel meslek gruplarından gelen bu göçmenlerin bir kısmı, ailelerini beraberlerinde getiriyorlardı. Bu grubun üyeleri bugün aynı zamanda aktif halde çalışan bir çok Türk derneğinin de kurucularıdırlar (Kaya, 2003).

Karpat'a (1995) göre 1948-1980 arasında ABD'ye gelen profesyonellerin sayıs1, 10 ile 50 bin arasında değişmektedir. Bu profesyonellerin de bir kısmı Türkiye'ye dönmesine rağmen, büyük kısmı ABD'ye yerleşmiştir. Türkiye ile ABD arasında başlayan yakınlaşma, Türkiye'nin 1952 yılında NATO'ya üye olması ile zirve noktaya ulaşmış ve profesyonellerin ABD'ye göç etmesine ivme kazandırmıştır. 1950 öncesi yıllık Türk göçmen sayısı 100'ün altında iken, 1970'li yıllar ile birlikte iki bine çıkmıştır. Profesyonel meslek gruplarının (mühendis, doktor ve mimar gibi) ABD’ye ilgi duymasının en önemli sebeplerinden birisi, ABD eğitim sisteminin yararcı olması ve pratikliği ön plana çıkarmasıydı. Eğitimin bu çekiciliği göçün tek sebebi değildi elbette. Eş zamanlı olarak, Menderes hükümetinin Doğu ve Güneydoğu bölgeleri için getirdiği zorunlu hizmet şartı da, Türkiye dışına çıkma yönünde itici bir faktör oldu. New York'ta 2001 yılında kendisiyle röportaj yaptığım emekli bir doktor bu bilgileri teyit etmiş, hatta aynı esnada Almanya'ya da eğitim maksadıyla gidenlerin olduğunu söylemişti (Kaya, 2003).

Bu profesyonel grup, Amerikan toplumu içinde orta ve yüksek sınıf vatandaşlar olarak yer bulmakta gecikmemiştir. Eğitim düzeyleri ve yüksek gelirleri bunu büyük ölçüde kolaylaştırmıştır (Ahmed, 1986). Birçokları, Amerikalı bayanlar ile evlenerek entegre olma yönünde hızlı bir süreç yaşarken, Türk kültür ve ulusçuluğunu da tanıtmak ve desteklemekten geri durmadılar (Bilge, 1996). Bunu hem kişisel çabaları, hem de kurdukları dernekler vasıtasıyla yapmışlardır.

Bu dönemdeki Türk göçü, sadece yüksek eğitimli profesyonel insanlarla sınırlı değildi. 1965 yılı göçmenlik yasasındaki yeni düzenlemeler ile birlikte, bir kısım teknik bilgilere sahip meslek 
kollarından da göç edenler vardı. Rochester şehrine gelen terzi grubu buna güzel bir örnek teşkil eder. ABD tekstil endüstrisindeki işçi ihtiyacından dolayı gelen terziler, dikiş atölyelerinde çalışmaya başlamışlardır (Ahmed, 1986). Bugün Rochester'daki Türk toplumu büyük ölçüde göçmen terzi grubunun kurduğu bir topluluktur. Bunlar, profesyonel grubun aksine, daha muhafazakar kültürel arka-planlardan geliyorlardı. Rochester bölgesindeki Türk camilerinin açılmasında da bu grubun ciddi katkıları olmuştur.

İkinci göç dalgası içinde dikkati çeken diğer bir grup ise eski Sovyetler Birliği sınırları içinde yaşayan değişik Türk grupları ve bunların ABD'ye göçleridir. Sovyet baskısından kurtulmak isteyen Kırım ve Kafkas Türkleri, ABD'nin sağladığı ayrıcalıklardan faydalanarak 1960 ve 1970'li yıllarda ABD'ye göç etmişlerdir. New York ve New Jersey çevresinde yaygın olarak yaşayan Karaçay ve Kırım Türkleri bu nedenle ABD’ye göç eden Türklerdendirler. Bugün New York çevresindeki Türk toplumu içinde aktif olan bu topluluklar, Türk gününde de diğer Türkler ile birlikte Madison Avenue'de her yıl yürüyerek Türk birliği düşüncesine desteklerini göstermektedirler (Kaya, 2004).

\section{4 Üçüncü Dalga: Karma Grup}

Küreselleşme, Türkiye içinde 1980 sonrası yaşanan siyasal, sosyal ve ekonomik değişimler/dönüşümler ve bunların etkisiyle oluşan yeni dünya görüşü, Türkiye'deki insanların daha geniş kitleler halinde dışarıya ilgisini arttırdı (Barkey, 2000). Özellikle Özal'ın 1980'li yıllardaki dışarıya açılım politikaları, ekonomi ile sınırlı kalmayıp, Türk toplumunun değişik kesimleri üzerinde sosyal ve kültürel etkiler yaparak dünyaya bakışlarını da etkilemiştir (Ergil, 2000). Basının ve özellikle de televizyonun Türkiye dışındakı dünyayı tanıtmadaki rolü, bir çok Türk insanının başka ülkelerde firsat kollaması için ufuk oluşturdu. Bu yeni durum, Türk toplumu içindeki her sosyal sınıfı ve siyasi düşünceyi etkileyerek, önemli bir dönüşüm ile sonuçlandı (Güvenç, 1998). ABD'nin dünyadaki rakipsiz pozisyonu ve cazibesi bir çok Türk'ün de ilgisini çekmiştir (Kaya, 2004). Bunun yanısıra, ABD'de alınan eğitimin getirdiği ayrıcalıklar, ABD'ye yönelişleri önemli ölçüde arttırmıştır (Şekil 2 ve 3). Özellikle Özal vizyonundan etklinen muhafazakar/dindar kesimler de, önceki dönemlere nazaran ABD'ye daha fazla ilgi duymuştur. 1980'li y1llar oldukça kozmopolit bir göçmen grubun ABD'ye yönlendiği bir dönemdir (Kaya, 2003). Kol gücü ile çalışan işçiden, üniversite mezunu gençlere, dindar ve muhafazakar gruplardan, ülkücü ve solcu gruplara kadar, oldukça geniş bir yelpazeden kadın ve erkek Türk insanı ABD’ye göç etmiştir (Çizelge 1). Örneğin, ilk göç dalgalarındaki Türkler arasında kadınların oranları \%25'lerin altında iken, son dalga içindekilerin oran $1 \% 45^{\prime}$ lere varmıştır.

Çizelge 1: ABD'de ki Türklerin kadın-erkek oranları.

\begin{tabular}{ll}
\hline Kadın & $\% 44.5$ \\
Erkek & $\% 55.5$ \\
Toplam & $\% 100$ \\
\hline Kaynak: United States Census, 1990. &
\end{tabular}

Bugün ABD'deki Türk öğrenci sayısı 15 bini aşmış ve bu sayı ile Türkiye ABD’ye eğitim amacıyla öğrenci gönderen ülkeler arasında dokuzuncu sırada yer almaktadır (AA, 2003). ABD'de ki yüksek eğitim ücretlerine rağmen, her yıl binlerce Türk öğrenci farklı finansal kaynaklar bularak, bu ülkeye eğitim maksadıyla gitmektedir. Milli Eğitim Bakanlığı ve Yüksek Öğretim Kurumu'nun gönderdiği burslu öğrencilerin yanısıra Amerikan üniversitelerinden asistanlık ve burs bulup gelen Türk öğrenci sayısı da binlerle ifade edilmektedir (Kaya, 2003). Ayrıca, kendi imkanlari ile ABD'ye gelerek okuyan Türk öğrencilerin sayısında da son yıllarda ciddi artışlar olmuştur. Bunlar dışında hem çalışıp hem de okuyanların sayısı da az değildir. Çalışarak okuyan Türk öğrencilerinin arasında, bu zor şartlar altında okul ve iş hayatını beraber götüremeyip, sadece çalışmaya yönelenleri olsa da, okulunu bitirip ABD'de iş bulanlar da az değildir (Kaya, 2004). 


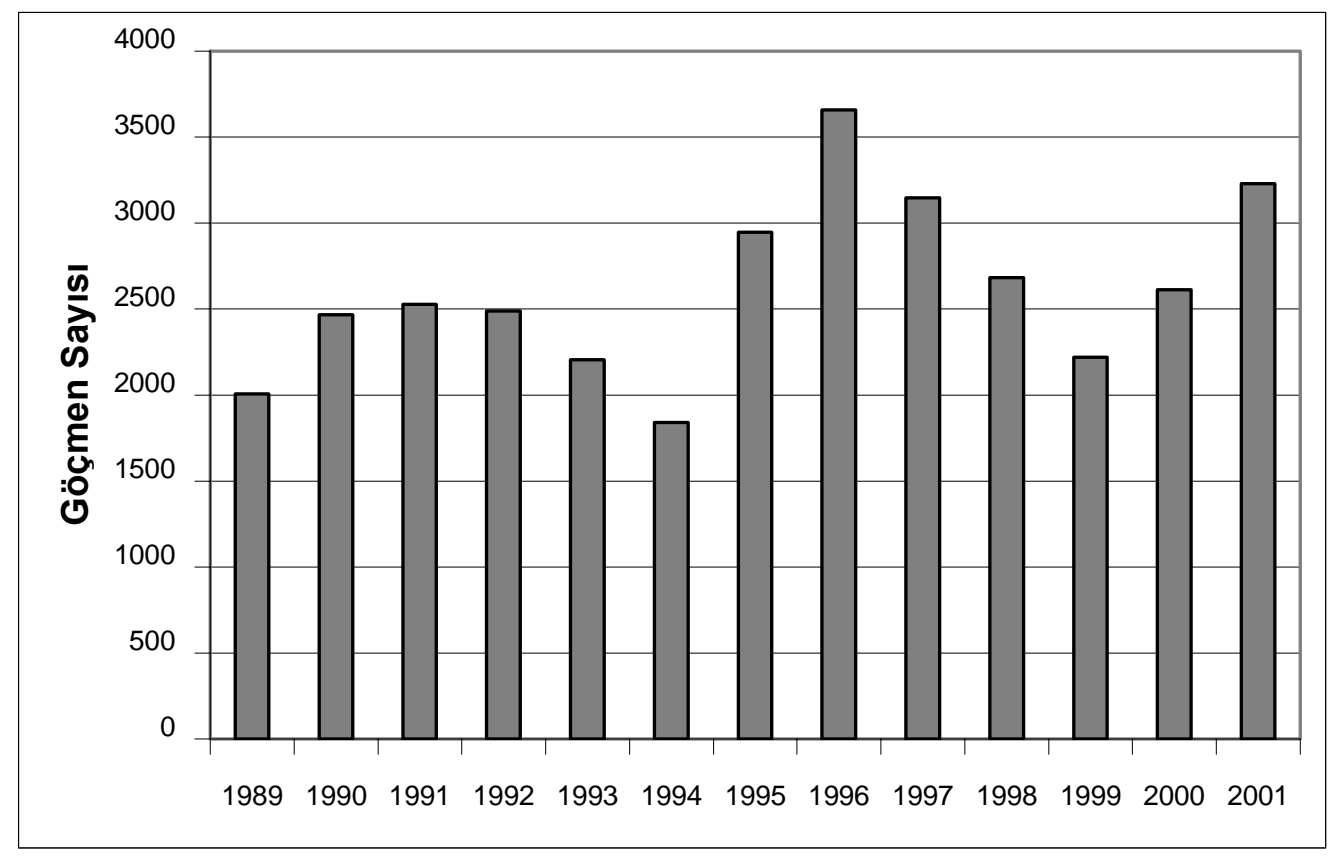

Şekil 3. Türklerin ABD’ye göçleri (1989-2001).

Kaynak: United States Immigration and Naturalization Service, 2000.

Üçüncü göç dalgası içinde gelen diğer bir grup ise, ilk göçmen dalgasında olduğu gibi niteliksiz ya da yarı nitelikli Türklerden (işçilerden) oluşmaktadır. Avrupa'da oluşan olumsuz iş imkanları, bir çok Türk'ü ABD'ye yönlerdirmiştir (Karpat, 1995). Bunların bir kısmının lise eğitimi varken, diğer kısmının eğitim düzeyleri daha düşüktür (Çizelge 2). Bir çoğu yasadışı yollardan ABD'ye giden bu Türkler, restaurant, market ve benzin istasyonlarında çalışarak hayatlarını sürdürmektedirler. Zamanla yasal statüye geçenlerin yanında, hala yasadışı statüde olanlar da az değildir. Çalıştıkları kargo şirketlerinin gemileriyle ABD’ye gelen bu Türkler, gemi limana yanaştıktan sonra, Türkiye'ye dönmemek üzere gemilerini terk etmektedirler (Ahmed, 1986). Vize alarak ABD'ye giden fakat vize tarihi geçmesine rağmen, ABD'de kalıp kaçak duruma düşen Türklerin sayısı da oldukça yüksektir.

Çizelge 2. ABD'de ki Türklerin eğitim seviyeleri.

\begin{tabular}{lrr}
\hline Lise ve yukarıs1 & 81.4 & 36,529 \\
Üniversite ve yukarıs1 & 40.9 & 18,352 \\
Master-Doktora & 22.1 & 9,923 \\
Toplam & 100 & 44,872 \\
\hline Kaynak: United States Census, 1990. & &
\end{tabular}

Yasadışı olarak ABD’ye giden Türkler, diğer Türklerin çalıştıkları iş yerlerinde çalışmaya başlayıp, kira ücretlerinin nisbeten düşük olduğu Paterson, New Jersey ve Brooklyn, New York gibi semtlere yerleşmektedirler. İngilizce seviyeleri genelde düşük olan bu Türklerin, Amerikan toplumundan kopuk bir şekilde yaşayarak gettolaştığ1 ifade edilmektedir. Uğur Akıncı Amerikan Türkleri arasındaki bu yeni eğilimi değerlendirirken, Amerikalı Türkler ile Almanya'da ki Türkler arasında paralellelikler kuruyor ve yaşanan olayı "Amerikan Türklerinin Almanlaşması" gibi ilginç bir metafor ile karakterize etmektedir (Akinci, 2002). Son göç dalgası içinde ABD’ye giden Türkler, Almaya gibi Avrupa ülkelerine giden Türklere benzerlikler gösterseler de, eğitim düzeyleri daha yüksek ve ABD toplumu içinde kabulleri ise daha olumludur. Paterson'a klasik anadolu kahvehane kültürünü taşıyan Türklerin yanında, Broadway'de müzikal izleyenler de az degildir. Paterson'daki 
durum, bütün Amerikalı Türkler için genellenecek bir olay olmayıp, ABD'deki Türklerin çeşitliliği açısından ilginç örneği temsil etmektedir.

\section{Türklerin ABD'de ki Sayıları ve Dağılımları}

Türklerin ABD'deki sayıları hakkında kesin bir şey söylemek neredeyse imkansızdır. ABD göçmen servisine göre 1820-2000 tarihleri arasında Türkiye'den ABD'ye 450,539 kişi göç etmiştir (INS, 2001). Ancak daha önce bahsedildiği gibi bu rakam Osmanlı Devleti ve Türkiye'den gelen gayri-müslim vatandaşları ve Türkler dışındaki müslüman grupları da içermektedir. İkinci Dünya Savaşından sonra Türkiye'den ABD'ye göç eden göçmenlerin çok büyük bir kısmı etnik Tüklerden oluşmaktadır (Kaya, 2004). Bu anlamda İkinci Dünya Savaşından sonra ABD’ye göç eden Türklerin sayısı hakkında verilen rakamlar daha gerçekçi olsa da, ABD'deki bütün Türklerin sayısı hakkında kesin bir şey ifade etmemektedir. Bu rakam ABD'de doğan Türkleri içermediği gibi, yasadış1 yollardan ABD'ye giren Türkleri de ihtiva etmemektedir.

İkinci bir kaynak olarak ABD Sayım Bürosunun rakamlarına bakıldığında da sorun çözülmemektedir. Sayım bürosuna göre, 2000 sayımlarında 117,619 kişi kendisini Amerikalı Türk olarak tanımlamıştır (EuroAmericans.net, 2003). Fakat bu rakam ABD'de yaşadığı tahmin edilen Türklerin rakamlarının çok gerisindedir. Eski New York Konsolosu Mehmet Ezen'in bu makalenin yazarına verdiği bilgilere göre ABD'deki Türklerin sayıs1 350 binin üzerindedir. Ezen'in tahminleri kendileri Türk konsolosluğu ile işlem yaptıran kişilerin sayısına dayanmaktadır. Ezen'in tahminleri ile Amerikan Sayım Bürosu rakamları arasındakı fark anlaşılır bir farktır; çünkü sayım bürosu'nun yaptığı kategorilerde, Türk kategorisi yer almamaktadır. Türk kökenli bir kişinin kendini Türk olarak kayda geçirmesi için "diğer" seçeneğini seçerek, kendini Türk-Amerikan olarak tanımlaması gerekmektedir. Ancak bir çok Türk bunu yapmayıp, "Beyaz" (White) seçeneğini işaretlemektedir. Bu da, sayımlarda Türklerin rakamının düşük olmasına sebep olmaktadır. Sayımlardaki Türk nüfusunun düşük olmasının diğer bir sebebi ise, Türkler arasında sayımlara katılım oranının düşük olmasıdır. Özellikle yasadışı olarak ABD'de bulunan Türklerin sayımlardan kaçtığı da unutulmamalıdır. Bunun yanında ABD'de geçici kalmayı düşünen Türkler'in de sayımlara ciddi ilgi gösterdiği de söylenemez (Kaya, 2004).

Son olarak belirtilmesi gereken diğer önemli bir nokta ise Azerbaycan, Kırım, Özbekistan vs. gibi Türkiye dışındaki bölgelerden ve ülkelerden gelen kişilerin, Türk dışında değişik kimlikler ile tanımlanmasıdır. Örneğin Azarbaycanlı Türkler Türk günü yürüyüşüne iştirak etmesine ve bir çok konuda diğer Türklerle hareket emelerine rağmen, kendilerini daha çok Türk yerine Azeri olarak tanımlamaktadırlar. Bu durum ABD'de ki Türklerin sayısının Konsolos Mehmet Ezen'in tahmini olan 350 binden daha fazla olabileceğini göstermektedir (Kaya, 2004).

Türklerin ABD'deki dağılımı da oldukça düzensizdir. Büyük bir çoğunluk New York, New Jersey ve Connecticut üçgeninde yaşamasına rağmen, California, Florida, Texas, Illinois, Massachusetts ve Pennsylvania gibi eyaletler de önemli ölçülerde Türk nüfusuna sahiptir. Alaska'dan Hawaii'ye kadar her eyalette az da olsa Türk'e rastlamak mümkündür (Şekil 4).

New York şehri Türklerin yaşamak için tercih ettikleri yerlerin başında gelmektedir. Ferris'e (1995) göre bugün 70 ile 100 bin arasında Türk, New York şehrinde yaşamaktadır. New York şehrinin Brooklyn bölgesinde Brighton Beach ve Coney Island, Queens bölgesinde Sunnyside ve Richmond Hills, Manhattan bölgesinde ise Rivington ve Forsythe Streets semtleri, Türklerin yoğunlukta yaşadığ yerlerdir (Ferris, 1995). New York'un yanısıra, Türkler Paterson, Clifton ve Clifside Park gibi New Jersey'nin New York'a çok yakın mesafede olan şehirlerinde de yoğunlukta yaşamaktadırlar.

Bir çok Türk, New York ve çevresinde kendi işini kurarak iş dünyasında pay sahibi olmaya çalışmaktadır. Türklerin ağırlıkta ilgi duyduğu işler arasında restaurant, benzin istasyonu, süpermarket işletmeciliği ile inşaatçllık ve taksi şoförlüğü gibi küçük meslek kolları başta gelmektedir (Ferris, 1995). Küçük Türk işletmecilerin yanında, eğitim düzeyi ve İngilizce seviyesi düşük Türkler, daha çok New York ve çevresini yaşamak ve çalışmak için seçmektedirler. Genel olarak ABD'ye göç eden Türklerin eğitim düzeyleri Avrupa'ya göç eden Türkler'inkinden daha yüksek olsa da, İngilizceye 
hakimiyet, iş bulmakta belirleyici bir faktördür. New York çevresinde oturmuş Türk toplumu, ABD’ye yeni gelen bir çok Türk için cazibe merkezi oluşturmaktadır; çünkü daha önce gelmiş olan göçmenler, yeni gelenlere ya kendilerinin açtıkları işyerlerinde iş olanakları sağlamakta ya da çevreyi bildiklerinden yeni gelenlerin kısa süre içinde iş bulmalarına yardımcı olmaktadırlar (Kaya, 2003). Bu anlamda Türklere ait restaurantlar, süpermarketler ve benzin istasyonları, İngilizce düzeyi düşük bir çok Türk'e iş imkanları sunmaktadır (Karpat, 1995). Zamanla İngilizceyi öğrenen Türkler, daha geniş seçenekler arasında tercih yapma fırsatı bulmakta ve böylece hem Türklerin işlettikleri işyerlerinin dışındaki yerlerde çalışma imkanı elde etmekte, hem de New York dışındaki eyaletlerde şanslarını denemektedirler.

Eğitim düzeyi yüksek ve profesyonel meslek dallarında uzmanlaşmış Türkler için, İngilizcenin kısıtlayıcılığ 1 çok daha sınırlıdır. Bundan dolayı ABD'nin hemen her eyaletinde bu grup Türklere rastlamak mümkündür. Florida ve California gibi eyaletler, bu yüksek eğitimli Türklerin öncelikle tercih ettiği eyaletler arasındadır. California'daki ileri teknoloji firmaları önemli bir çekici faktördür. Florida ise daha çok emeklilik yaşına gelen yüksek gelirli yaşlıların tercih ettikleri bir eyalettir. Dolayısıyla emekliye ayrılan bir çok zengin Türk diğer etnik grup mensupları gibi bu eyaleti iyi iklim koşullarından dolayı tercih etmektedirler. Amerikan toplumunda orta ve yüksek sınıf içerisinde kendilerine yer bulan yüksek eğitimli Türkler, Amerikan toplumuna daha çabuk entegre olmaktadırlar. Hem beraber oldukları insanlar Türklerle sınırlı değilir, hem de yaşadıkları semtler, ağırlıkta Amerikalıların yaşadığı yerlerdir. Paterson'da olduğu gibi bir gettolaşma sözkonusu değildir (Kaya, 2003).

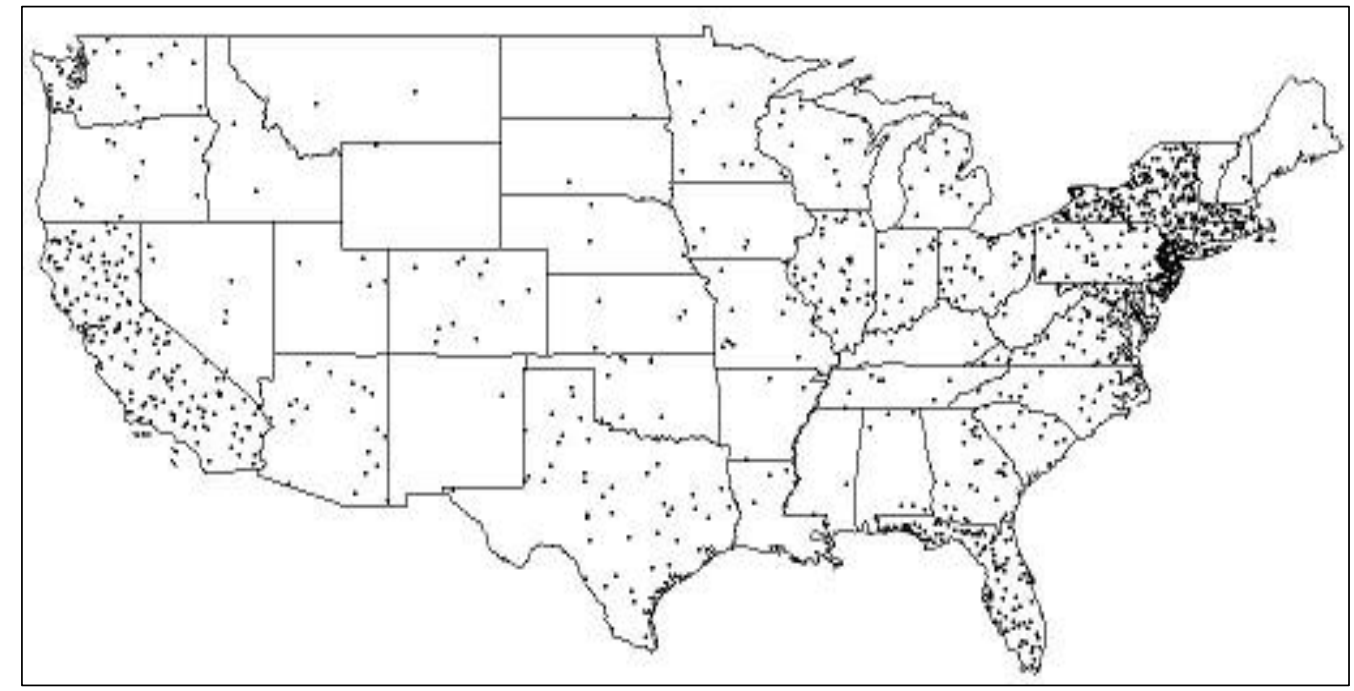

Şekil 4. Türkler'in eyaletlere göre dağılımı. Kaynak: United States Census, 2000.

Bugün Türkler ABD'de her geçen gün varlıklarını daha da hissettirme gayreti içindedirler. Kurulan Türk dernek ve birlikleri, Türk toplumunu bir araya getirerek, Amerikan toplumu içinde daha tesirli olmaya çalışmaktadır. Amerikan Türk Dernekleri Federasyonu ve Amerika Türk Dernekleri Birliği ABD'deki Türk derneklerini bir araya getirerek, çatı görevini üstlenmektedirler (Altschiller, 1995). Hemen her eyalette kurulan Türk derneklerinin yanında, neredeyse bütün büyük Amerikan üniversitelerinde Türk öğrenci derneklerine rastlamak mümkündür. Son y1llarda Türk hükümetlerinin teşvikleriyle daha da organize olan Türk dernekleri, Türk kültürünü yayma ve Türkiye'yi tanıtmayı kendilerine görev saymaktadırlar. Bunun yanında hala çok cılız kalsa bile, çatı derneklerin Türkiye adına lobi faaliyetleri de söz konusudur. Her yıl 19 Mayısa en yakın Cumartesi günü yapılan Türk 
Günü yürüyüşü, hem bir boy gösterisi sayllmakta, hem de Türklerin bir araya gelerek birlik mesaji verdikleri bir faaliyet olarak görülmektedir. Bunun yanında Türk Günü’nün Türk kültürünü tanıtma gibi bir fonksiyonu da sözkonusudur (Kaya, 2003).

Sayısı giderek artan başarılı Türkler, Amerikan toplumu içinde varlıklarını her geçen gün daha da hissettirmektedirler. Bu şekilde kendisini Amerikan toplumuna kabul ettiren Atlantic Records'un sahibi Ahmet Ertegun gibi müzik dünyasının önemli isimleri yanında, Mehmet Öz gibi ABD'de iyi bilinen doktor ve akademisyenlerin sayısı her geçen gün artmaktadır. Bu isimler sadece birer başarı örnekleri değil, aynı zamanda Türkiye'nin gönüllü tanıtıcılarıdır (Kaya, 2003).

\section{Sonuç}

$\mathrm{Bu}$ makalede Türklerin ABD’ye göçleri, üç önemli göç dalgası halinde ele alınmıştır. Birinci dalga daha çok Osmanlı köylüsünü temsil eden, hemen hemen hepsi erkeklerden oluşan, 1820'de başlayıp Birinci Dünya savaşı ile sona eren Türk göç hareketiyle karakterize olur. Birinci Dünya Savaşı öncesinde ABD'ye giden bu Osmanlı Türklerinin, hem eğitim seviyeleri çok düşüktü, hem de ABD’ye kalıcı olarak gelmemişlerdi. Zaten Birinci Dünya Savaşının sona ermesi ve Türkiye Cumhuriyetinin kurulmasi ile, ABD'ye gelen 45-65 bin Türk'ün yarıya yakını Türkiye'ye dönmüştür (Halman, 1980). Kalanlar ise Amerikalılar ve diğer göçmenler ile evlenerek Amerikan toplumu içinde eriyip gitmişlerdir.

İkinci Dünya Savaşı sonrası Türkiye ve ABD arasında yaşanan yakınlaşma, ikinci göç dalgasının en önemli sebeblerinden birisi olmuştur. Türkiye'nin 1952 yılında NATO'ya üye olmasi ile Türkiye'den ABD'ye yaşanan göç hareketi, 1965'ten sonra ciddi ölçüde artış göstermiştir (Karpat, 1995). ABD’nin 1924'den beri Türkiye'ye uyguladığ1 göç kotası, 1965 Amerikan göçmenlik yasasındaki değişikliklerle birlikte ciddi bir şekilde yumuşamış ve bir çok ülkenin yanında Türkiye'den ABD'ye göçün büyük ölçüde artmasını sağlamıştır. Bu yakınlaşma ile birlikte Türkiye'den ABD'ne profesyonel meslek gruplarından (doktor, mimar, mühendis ve akademisyen gibi) eğitim amaçlı yeni bir göç akını başlamıştır. Bunlar bugün bile devam etmekte olan Türkiye'den yurt dışına olan beyin göçünün de ilk temsilcileridir (Kaya, 2004). Bir önceki göç dalgasının aksine, bu dalga içinde erkekler çoğunluğu oluştursa da, kadın ve çocuklar da mevcuttu. Ulusçu kimlikleri ağır basan bu grup, şu anda ABD'de faaliyette olan bir çok Türk derneğinin kuruculuğunu yapmışlardır.

Son göç dalgası ise 1980'li yılların sonlarına doğru başlayan ve 1990'li yıllar ile giderek artan, oldukça kozmopolit Türkler ile temsil edilen göç dalgasıdır. Özellikle küreselleşmenin etkisi ve Avrupadaki iş imkanlarının giderek azalması ile Türk toplumunun her sosyal sınıf ve kesiminden (muhafazakar, liberal, kadın, erkek, zengin, fakir) ABD'ye yönelişler olmuştur (Kaya, 2003). Küreselleşmenin getirdiği kolay iletişim ve seyahat, bir çok Türk'ün ABD’ye ilgisini arttırmıştır. 2000'li yıllar itibariyle Türkiye'den ABD'ye göç yıllık dört bin gibi rakamlara ulaşmıştır.

ABD'ye göç eden Türkler'in Avrupa'nın değişik ülkerine göç eden Türklere oranla daha yüksek eğitim düzeyine sahip olmaları, Amerikan toplumuna entegrasyonlarını kolaylaştırmaktadır. ABD'nin bir göçmen ülkesi olması ve farklılıklar kabul etmeye daha açık olması, bu entegrasyonun daha yüksek düzeyde olmasına katkı sağlamaktadır. Özellikle ikinci kuşakta yaşanan Amerikalılaşmanın çok önemli olduğu aşikardır. İkinci kuşak Türkler, Amerikan kimliklerini Türk kimlikleri kadar benimsemekte ve bu farklı kimlikleri birbirleri ile çelişen tezatlar olarak görmemektedirler. İkinci kuşak ebeveynleri ile Amerikan toplumu arasında köprü vazifesi görmekte, iki farklı dünyayı aynı anda yaşamaktadırlar. Türkçe yerine İngilizceyi tercih eden ikinci kuşak Amerikalı Türkler, hiç bir zaman da ebeveynleri kadar Türkiye ile ilgili değildirler. Türkiye ile ilgili haberleri ancak ABD medyasında çıkarsa takip etmektedirler (Kaya, 2003). 


\section{Referanslar}

Anadolu Ajans1. (2003). Fifty Thousand Turkish Students Educated Abroad. Anadolu News Agency. Retrieved June 26, 2003, from the World Wide Web: http://www.turks.us/article.php?story=20030519170527753

Ahmed, F. (1986). Turks in America: The Ottoman Turk's Immigrant Experience. Connecticut: Columbia International Press.

Akinci, U. (2002). Germanification of Turkish-Americans. Retrieved September 28, 2003, from the World Wide Web: http://gencturkler2.8m.com/IMMIGRANTS/turkish_torque.html

Altschiller, D. (1995). Turkish Americans. In V. Rudolph (Ed.), Gale Encyclopedia of Multicultural America (Vol. 2, pp. 1364-1373). Detroit: Gale Research.

Appadurai, A. (1998). Modernity at Large : Cultural Dimensions of Globalization. Minneapolis, MN: University of Minnesota Press.

Appadurai, A. (2000). Globalization. Durham, NC: Duke University Press.

Bali, R. N. (2004). Anadolu'dan Yeni Dünya'ya: Amerika'ya Göç Eden Türklerin Yaşam Öyküleri.

Barber, B. R. (1996). Jihad vs. McWorld (1st Ballantine Books ed.). New York: Ballantine Books.

Barkey, H. J. (2000). State-Society Relations - The Struggles of a "Strong" State. Journal of International Affairs, 54(1), 20.

Benmayor, R., \& Skotnes, A. (1994). Migration and Identity. Oxford ; New York: Oxford University Press.

Bilge, B. (1996). Turkish-American Patterns of Intermarriage. In B. C. Aswad \& B. Bilge (Eds.), Family and gender among American Muslims: issues facing Middle Eastern immigrants and their descendants (pp. 327). Philadelphia: Temple University Press.

Cornell, S. E., \& Hartmann, D. (1998). Ethnicity and Race : Making Identities in a Changing World. Thousand Oaks, Calif.: Pine Forge Press.

Ergil, D. (2000). Indentity Crises and Political Instability in Turkey. Journal of International Affairs, 54, 43.

EuroAmericans.net. (2003). Population of European-American and other ethnic groups in the United States. EuroAmericans.net. Retrieved November 13, 2003, from the World Wide Web: http://www.euroamericans.net/census2000.htm

Ferris, M. (1995). Turks. In J. T. Kenneth (Ed.), The Encyclopedia of New York City. New York: Yale University Press.

Giddens, A. (2000). Runaway World: How Globalisation is Reshaping Our Lives. New York: Routledge.

Gordon, J. L. (1931). The Turkish American Controversy over Nationality. The Journal of International Law., 25, 658-669.

Gregory, D. (1995). Imaginative Geographies. Progress in Human Geography, 19, 447-485.

Guvenc, B. (1998). Secular Trends and Turkish Identity. Journal of International Affairs, II(4).

Halman, T. (1980). Harvard Encyclopedia of American Ethnic Groups. In S. Thernstrom (Ed.), Harvard Encyclopedia of American Ethnic Groups (pp. xxv, 1076). Cambridge, Mass.: Belknap Press.

INS. (2001). Statistical Yearbook. The U.S Immigration and Naturaliz Service. Retrieved January 15, 2003, from the World Wide Web: http://www.ins,gov

Jackson, P. (1994). Maps of Meaning : an Introduction to Cultural Geography. London ; New York: Routledge.

Karpat, K. (1995). Turks in America. In T. D. Stephane (Ed.), Les Annales de L'Autre Islam (Vol. 3, pp. 231-252). Paris: Erism.

Kaya, İ. (2003). Shifting Turkish American Identity Formations in the United States. Unpublished Dissertation, Florida State University, Tallahassee.

Kaya, İ. (2004). Turkish American Immigration History and Identity Formations. the Journal of Muslim Minority Affairs, 24. Lewis, B. (1961). The Emergence of Modern Turkey. London, New York,: Oxford University Press.

Palanithurai, G., \& Thandavan, R. (1998). Ethnic Movement in Transition: Ideology and Culture in a Changing Society. New Delhi: Kanishka Publishers Distributors.

Shanks, C. (2002). Immigration and the Politics of American Sovereignty, 1890-1990. Ann Arbor: The University of Michigan Press. 


\title{
TÜRKIYY'NIN GÜNEYDOĞUSUNDA NÜFUSUN ZORUNLU YERINNDEN OLUŞU: SÜREÇLER ve MEKÂNSAL ÖRÜNTÜ
}

\author{
Internal Displacement of the Population in South-eastern Turkey: \\ Processes and Spatial Pattern
}

\author{
M. Murat YÜCEŞAHİN \\ Ankara Üniversitesi, Dil ve Tarih-Coğrafya Fakültesi, Coğrafya Bölümü, 06100, Sıhhiye, Ankara \\ mmyucesahin@yahoo.com
}

\section{E.Murat ÖZGÜR}

Ankara Üniversitesi, Dil ve Tarih-Coğrafya Fakültesi, Coğrafya Bölümü, 06100, Sihhiye, Ankara ozgur@humanity.ankara.edu.tr

\begin{abstract}
Özet: Nüfusunun coğrafi hareketliliği ile tanınan Türkiye’nin geçmiş yirmi yılda dramatik bir biçimde tecrübe edindiği demografik olaylardan biri de önemli miktardaki nüfusun ülke içinde yerinden oluşudur. Çatışmalar ya da savaşlar, insan yerleşimi için güvensiz ortamın oluşumunu sağlayarak ülke içi yerinden olmaya neden olsa da Türkiye'de olduğu gibi, ayrllıçı silahl grupların yarattı̆̆ güvenli olmayan ortamı ortadan kaldırmayı amaçlayan uygulamalar ve politikalar da nüfusun zorunlu göçüne sebebiyet veren etkenlerden biri olabilmektedir. Türkiye'deki zorunlu göçler farklı etnik gruplar arasındaki çatışma ya da çöken Sovyetler Birliği ve Yugoslavya'da olduğu gibi siyasal çözülmenin bir ürünü değildir. Ülkenin güneydoğusunda isyancı güçler (PKK terör örgütü) ile Türk güvenlik güçleri arasındaki çatışmalar nedeniyle oluşan zorunlu göçler, bu bölgede eskiden beri egemen olan batıya yönelmiş iç göçleri artırmıştır. Zorunlu göçler özellikle kırsal nüfusu etkilemiş ve buralardaki insanlar çatışma bölgesindeki veya dışındaki kentlere yığllmışlardır. Bu göçlerin plansız oluşu, göç edenleri (Yerinden Olmuşs Nüfus (YON)) bireysel ya da aile olarak mağdur ettiği kadar onların sığındığ kentlerin sosyo-ekonomik dengesini de bozmuştur. Bu makale, güneydoğu Türkiye'de yaklaşık 1 milyon kişinin yerinden olmasına neden olan politik, psiko-sosyal ve ekonomik etkenleri ve bu etkenlerin oluşumunu (süreçler) ve zorunlu göçlerin meydana geldiği alanları göç doğrultularıyla (mekânsal örüntüler) birlikte iller/kentler düzeyinde sistematik olarak sorgulamaktadır. Bu çalışmada çatışmanın başlangıcı (1985 nüfus sayımı) ve durulduğu zaman (2000 nüfus sayımı) arasındaki nüfus sayımlarına yansımış ve tamamen nüfussuz hale gelmiş köyler ile göç istatistiklerinden yararlanılmıştır. Böylece Türkiye'de nüfusun yerinden olma süreci, mekânsal örüntüsü ve YON'ların yeniden yerleşmek için tercih ettiği yerleşmelerdeki durumları niteliksel olduğu kadar niceliksel açıdan da ele alınmıştır.
\end{abstract}

Anahtar Kelimeler: Yerinden olmuş nüfus, zorunlu göç, iç göç, boşalmış köy, Türkiye

\begin{abstract}
Turkey is a country known for the geographical mobility of its population and it is one of the most important events that Turkey has dramatically experienced in terms of demography within the past two decades. Although wars and conflicts create an insecure environment for human habitation which lead to internal displacement, another factor causing internal displacement can be practices and policies aiming to eliminate the insecure environment caused by separatist armed groups (PKK terrorist organization), as is the case in Turkey. Forced migrations in Turkey are not caused by conflicts between different ethnic groups or political dissolution as in the former Soviet Union or Yugoslavia. Forced migrations caused by the conflicts in south-eastern Turkey between Turkish security forces and rebel groups intensified
\end{abstract}

